\title{
Assessing evidence supporting redistribution of pressure for pressure ulcer prevention: A review
}

\author{
Stephen Sprigle, PhD, PT; ${ }^{*}$ Sharon Sonenblum, PhD \\ Rehabilitation Engineering and Applied Research Lab, Georgia Institute of Technology, Atlanta, GA
}

\begin{abstract}
The formation and underlying causes of $p$ ressure ulcers (PUs) are quite complex, with multiple influencing factors. However, by definition pressure ulcers cannot form without loading, or pressure, on tissue. Clinical interventions typically target the magnitude and/or duration of loading. Pressure magnitude is managed by the selection of support surfaces and postural supports as well as body posture on supporting surfaces. Duration is addressed via turning and weight shifting frequency as well as with the use of dynamic s urfaces that actively redistribute pressure on the body surfaces. This article shows that preventative interventions must be targeted to both magnitude and duration and addresses the rationale behind several common clinical interventions-some with more scientific evidence than others.
\end{abstract}

Key words: body posture, clinical interventions, postural supports, pressure magnitude, pressure ulcers, prevention interventions, support surface, tissue loading, turning frequency, weight shifting frequency, wheelchair.

\section{INTRODUCTION}

The formation a nd underlying $\mathrm{c}$ auses of pressure ulcers (PUs) are quite complex, with multiple influencing factors. However, by definition PUs cannot form without forces, or press ure, on tissue. Because tissue loading is the defining characteristic of PU formation, it naturally garners significant attention in research in PU prevention strategies.

Research has clearly demonstrated that the damaging effects of pressure are related to both its magnitude and duration. Simply stated, tissues can withstand higher loads for shorter periods of time. Kosiak first demon strated this characteristic 50 years ago by applying varying loads to the trochanters and ischial tuberosities of dogs for varying periods of time [1]. High loads for short durations and low loads for long durations induced ulcers, with the time-at-pre ssure curve following an inverse parabola. Reswick and Rogers tried to extend this animal research into clinically relevant information, and using combinations of interviews and interface pressure measurements (IPMs), de termined a pressure-time rela tionship that was similar to that of Kosiak [2].

Using the premise that both the magnitude and duration of loading are important, we can diagram a simple model of PU development (Figure 1) that illustrates the reasoning behind certain clin ical interventions. Pressure magnitude is managed by the selection of support surfaces and postural supports as well as body posture upon supporting surfaces. Duration is a ddressed via turning and weight shifting frequency as well as with the use of dynamic surfaces that a ctively redistribute pressure on the body surfaces.

\footnotetext{
Abbreviations: IPM = interface pressure measurement, Mobility $\mathrm{RERC}=$ Rehabili tation Engineering Research Center on Wheeled Mobility, $\mathrm{PU}=$ pressure ulcer, $\mathrm{SCI}=$ spinal cord injury.

*Address all correspondence to Stephen Sprigle, PhD, PT; Georgia Tech-Applied Physiology, 490 Tenth St NW, Atlanta, GA 30032-0156; 404-385-4302; fax: 404-894-9320. Email: sprigle@gatech.edu

DOI:10.1682/JRRD.2010.05.0102
} 


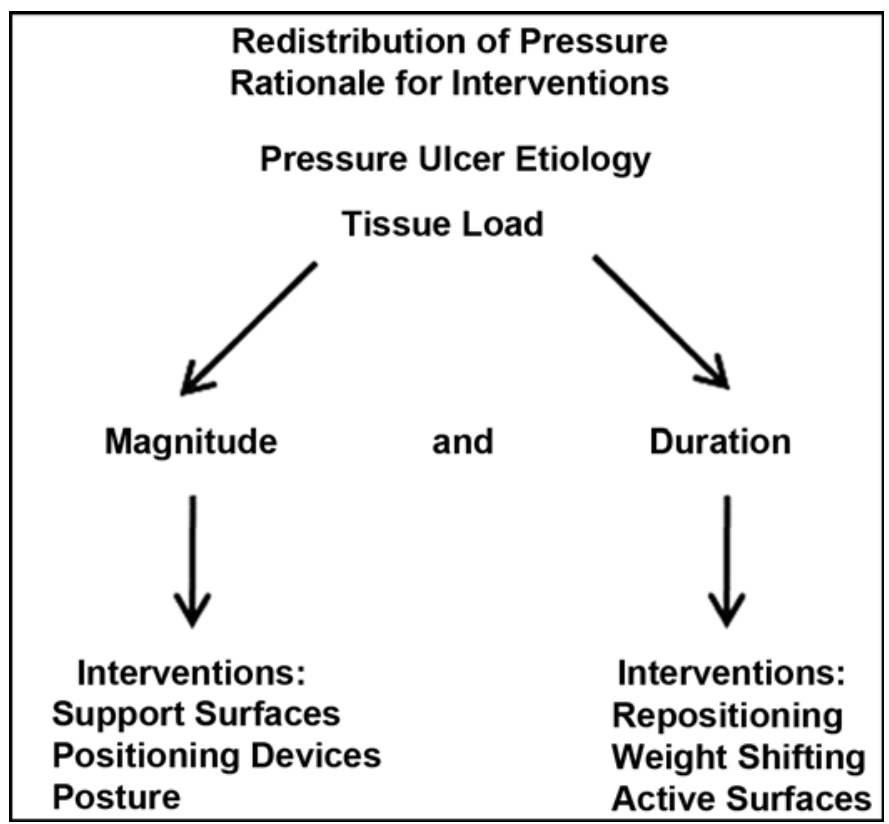

Figure 1.

Rationale for redistribution of pressure.

This article reviews the evidence supporting clinical interventions that address the magnitude of pressure and the duration of that pressure. Within this article, "support surfaces" will refer to devices designed for horizont al (mattresses, overlays) and s eated (wheelchair cushions) postures. The term "pressure" will refer to the force or load exerted over an area of the body or on a localized area of the body surface.

\section{CONTROLLED EXPERIMENTS OF TISSUE LOADING}

A fairly extensive amount of re search has applied loads to tissues and monitored physiological outcomes. For obvious re asons, research with animal models uses controlled loading to create PUs or tissue necrosis, whereas human studies are limited to indirect measures, such as the effect of loading on blood flow.

\section{Tissue Response to Loading in Animal Models}

As mentioned previously, Kosiak u ndertook seminal research by applying load $\mathrm{s}$ to the trochan ters and isch ial tuberosities of dogs [1]. Load $\mathrm{s}$ ranged from 100 to $500 \mathrm{mmHg}$, and durations ranged from 1 to 12 hours.
Kosiak monitored animals for 14 days postischemia to determine the occurrence of PUs. Dinsdale applied pressures between 45 and $1,500 \mathrm{mmHg}$ for 3 hours to swine with and without paraplegia [3]. Normal pressure was combined with friction in half the specimens. The results indicated that no necrosis occurred with normal pressures below $150 \mathrm{mmHg}$, but in combination with friction, tissue changes could be seen after loading with $45 \mathrm{mmHg}$. Daniel et al. also studied swine with and without paraplegia [4]. Using an indenter to apply load at the greater troch anter, they found that application of $200 \mathrm{mmHg}$ for 15 hours did not induce a PU. Ulcers were obtained by applyin $\mathrm{g}$ $500 \mathrm{mmHg}$ for 4 hours and $800 \mathrm{mmHg}$ for 8 hours.

Linder-Ganz and Gefen exposed rat hind limbs to pressure magnitudes of 86,262 , and $525 \mathrm{mmHg}$ for 2, 4, and 6 hours, respectively [5]. They used finite element modeling to calculate internal stresses and concluded that tissue damage occurred with $13 \mathrm{kPa}$ of internal stress applied for 6 hours and $40 \mathrm{kPa}$ of interna 1 stress applied for 2 ho urs. Both conditions represent an approximate stress application rate of $80 \mathrm{kPa} / \mathrm{h}$.

While this is not a comprehensive list of animal PU etiology research, collectiv ely the studies illustrat e results obtained by applying different loads over different durations (Table). The use of different sizes and shapes of indenters, different loading parameters, and different animal models explains why a range of mag nitudes and durations are linked to PU development. Despite these differences, the evidence suggests that both magnitude and duration of loa ds must be considered in PU preven tion and validates the simple intervention model in Figure 1.

\section{Blood Flow Response to Loading in Humans}

While research has clearly shown a rela tionship between pressure magnitude and duration and tissue damage, these studies have not de fined a critical ma gnitude above whic h ischemia occurs. Many studies have used controlled experimental approaches for determining the pressure at whic $\mathrm{h}$ blood flow to tissue cea ses with significantly varying results. Lassen and Holste in found that the pressure required for vascular occlusion approximated diastolic pressures when the measured skin approached heart level [6]. Holloway et al. loaded the forearm and found that blood flow decreased as external pressure approached mean arterial pressure and that occlusion was reached at $\sim 120 \mathrm{mmHg}$ [7]. Ek et al. found "weak positive correlations" between blood flow during 
Table.

Examples of animal pressure ulcer models highlighting different loading parameters.

\begin{tabular}{|c|c|c|c|}
\hline Author & Animal Model & Loading Conditions & Outco \\
\hline osiak [1] & $\begin{array}{l}\text { Canine trochanter and } \\
\text { ischial tuberosity }\end{array}$ & $100-500 \mathrm{mmHg}$ over $1-12 \mathrm{~h}$ & $\begin{array}{l}\text { Proposed inverse magnitude-duration } \\
\text { relationship. }\end{array}$ \\
\hline insdale [2] & $\begin{array}{l}\text { Swine with and without } \\
\text { spinal injury }\end{array}$ & $\begin{array}{l}45-1,500 \mathrm{mmHg} \text { over } 3 \mathrm{~h} \text { with } \\
\text { and without friction }\end{array}$ & $\begin{array}{l}\text { presence } \\
\text { e. }\end{array}$ \\
\hline aniel et al. [3] & $\begin{array}{l}\text { Swine with and without } \\
\text { spinal injury }\end{array}$ & $\begin{array}{l}\text { for } 15 \mathrm{~h}, 500 \mathrm{mmHg} \\
0 \mathrm{mmHg} \text { for } 8 \mathrm{~h}\end{array}$ & $\begin{array}{l}\mathrm{Hg} \text { for } 15 \mathrm{~h} \text {, } \\
\text { her conditions. }\end{array}$ \\
\hline \multicolumn{4}{|c|}{$\begin{array}{l}\text { 1. Kosiak M. Etiology and pathology of ischemic ulcers. Arch Phys Med Rehabil. 1959;40(2):62-69. [PMID: 13618101] } \\
\text { 2. Dinsdale SM. Decubitus ulcers in swine: Light and electron microscopy study of pathogenesis. Arch Phys Med Rehabil. 1973;54(2):51-56. [PMID: 4692634] } \\
\text { 3. Daniel RK, Wheatley D, Priest D. Pressure sores and paraplegia: An experimental model. Ann Plast Surg. 1985;15(1):41-49. [PMID: 4083714] } \\
\text { DOI:10.1097/00000637-198507000-00005 } \\
\text { 4. Linder-Ganz E, Gefen A. Mechanical compression-induced pressure sores in rat hindlimb: Muscle stiffness, histology, and computational models. J Appl Phys- } \\
\text { iol. 2004;96(6):2034-49. [PMID: } 14766784] \\
\text { DOI:10.1152/japplphysiol.00888.2003 }\end{array}$} \\
\hline
\end{tabular}

loading at the heel and systolic blood pressure [8]. Loading at the sac rum did not resu lt in the same relationship with blood pressure. Sangeorzan et al. de termined that $71 \mathrm{mmHg}$ was need ed to occlude flow over the tibialis anterior (a "soft" site) but only $42 \mathrm{mmHg}$ occluded flow over the tibia (a "hard" site) [9]. Bennett et al. measured occlusion pressure at the thenar eminences of nondis abled subjects and found that 100 to $120 \mathrm{mmHg}$ was necessary to occlude v essels in "low shear" conditions and 60 to $80 \mathrm{mmHg}$ was needed in the pre sence of "high shear" conditions [10]. Bar re viewed the literature and concluded that a critical pressure is necessary to occlude blood flow and that while this threshold is related to vessel pressure, it appears to vary widely [11].

The animal and human studies contribute important information to the field of PU research by identifying tissue's response to external loads. However, the results are very hard to apply clinically. Controlled loading at specific anatomical sites simply doe s not generalize to the person lying in bed or sitting in a wheelchair. For example, the magnitudes and durations of loading used to induce dam age in animals greatly exceed those deemed a cceptable in clinical environments. This apparent discrepancy does not invalidate either the research or the clinical interpretation of the findings. Rather, these animal tests inform us about the mechanism of injury and the complex relationships between the variables involved when supporting the human body in sitting or lying positions.

To date, research has not identified a specific threshold at which loads can be deemed harmful across people or sites on the body. Tissue's tolerance to load varies according to the condition of the tissue and its location, age, hydration, and metabolism. All the factors common to PU risk assessment tools tend to influence how the tissue distributes the loading and its ability to wi thstand load.

\section{EVIDENCE SUPPORTING CLINICAL INTERVENTIONS}

\section{Support Surfaces}

Support surfaces attempt to redistribute forces away from bony prominences, thereby reducing the magnitude of loading at these at-risk sites. In general, creating suc cessful support surfaces is challenging because of the differences in ind ividual risk factors, as well as the complicated nature by which force is distributed throughout tissue. For example, when a person sits on a cushion, normal loading works in combination with shear and frictional forces to induce complex tissue distortion. Consequently, myriad support surface designs ex ist that have benefit for some people, but for the most part, no single surface is optimal for all persons. Two very general categories of support surfaces can be defined: reactive surfaces that respond to the load placed upon them and active surfaces that dynamically a lter the body-support-surface interface. Although active surfaces serve as a duration intervention, their primary role as a supp ort surface (thus affecting magnitude of loading) makes it natural to present them together with reactive support surfaces. 
Judging the effectiveness of support surfaces is done with both direct and indirect methods. Indirect methods use physiological means such as blood flow, tissue oxygenation, and interface pressure to judge performance. Direct methods follow a group of patients over time to determine PU occurrence. Direct methods are more valuable but are harder to adminis ter and are limited in the number of interventions that can be inve stigated (i.e., types of surfaces).

In their systematic review focused on randomiz ed controlled trials with PU development as an outcome, Cullum et al. used the term "constant low-pressure support surfaces" to describe the myriad foam, air, water, and elastomeric mattresses, overlays, and cushions [12]. Their review of the literature concluded that these surfaces outperform standard hospital mattresses in preventing PU formation. Comparisons between dif ferent constant low-pressure surfaces did not result in definitive outcomes. In othe $\mathrm{r}$ words, differences across the more common reactive surfaces have not been demonstrated in terms of PU outcomes.

Studies on wheelchair cushions are not as common as those on mattresses, but informative evidence is still available. Indirect measures, specifically interface pressures, comprise the bulk of studies on cushions [13-16]. Researchers have shown that high seated interface pressures were associated with PU occurrence [17-19]. Therefore, despite the limita tions in IPM as a less accurate representation of localized loading [5,20-22], it can be useful in selecting cushions.

Because active surfaces vary loading of pa rticular regions of the body, they intend to alter both the magnitude and duration of loading. Active surfaces are available for both mattresses and wheelchair cushions, with mattresses being use $\mathrm{d}$ and studie $\mathrm{d}$ more freque ntly. In part, this is the result of a funding decision in the United States by the Ce nters for Me dicare and Medic aid Services to not pay for powered wheelchair cushions for PU prevention. Evidence on commercially available a ctive cushions is limited to seco ndary outcomes $[16,23]$. Because the secondary measurements vary throughout the cycle of active cushions, the results of such studies are hard to apply clinically.

Studies of active mattresses and overlays a re more common than those of cushions and have used both direct and indirect outcomes. Two recent systematic reviews do a very thorough job of covering the literature on alternating pressure mattresses so the details will not be repeated here [12,24]. Cullum et al. focused exclusively on direct outcomes (PU development), while Vanderwee et al. extended their review to include studies with indirect outcome measurements and a lternative study designs. But both groups reached the same conclusions: alternating pressure air mattres ses are better than standard hospital mattresses but their bene fit over constant low -pressure mattresses is unclear. Furthermore, differences across types of alternating pressure air mattresses were not demonstrated. Active surfaces also provide increased potential for mechanical problems and user error compared with some alternatives. One major limitation of most of the reviewed studies, as pointed out by Cullum et al., was that turning schedules were not controlled. Therefore, it is possible that nurses made a point to turn patients on the standard mattresses more frequently than those on the active surfaces because of a perceived need for increased intervention. If true, than comparable outcomes could come with the benefit of re duced clinical intervention time for the active surfa ce, but research to evaluate this possibility is needed.

\section{Interventions for Reducing Duration of Loading}

The body's motor and sensory systems are responsible for ensuring that we move periodically to change our posture. This may be in the form of discomfort eliciting movement or subconscious postural shifts or fidgeting. Many studies over the years have monitored movements in chairs a s metrics of co mfort and function [25-28], thereby establishing a base of knowledge about sitting as a dynamic activity. Many people at risk of dev eloping PUs are either unable to effectively reposition themselves or are not provided with the sensory feedback that elicits movements. Therefore, that loss of mobility and sensation are identified as risk factors within every PU risk assessment scale is not surprising.

We use this information to tar get movement as a means of redistributing pressure and altering the duration of loading on tissues. Cli nically, this includes turning schedules for patients who are in bed and weight shifting strategies for those who are seated.

\section{Turning Frequency}

In a study on PU prevention interventions, Richardson et al. found that manual repositioning was the most commonly used intervention and that it was also the most expensive [29]. The idea of necessary repositioning has appeared throughout literature and textbooks since the 
1800s [30]. Evidence that some repositioning is necessary can be found across decades of literature.

In the United States, common practice requires that at-risk patients be repositioned at least every 2 hours if consistent with overall patient goals [31]. Despite efforts by a number of researchers to identify the origins of this practice, or at the very least identify evidence supporting the 2-hour turning practice, no strong scientific support exists [30,32-33]. In fact, earlier texts often included suggestions that the turning schedule depend on the magnitude of loading and condition of the patient.

Therefore, the standard practice of using the sa me turning schedules independent of support surface is not reflective of earlier work. Recent evidence demonstrates the need to account for the support surface in determining the optimal turning schedule. Defloor et al. showed that 2- and 3-hour turning schedules resulted in the development of PUs in 14 to 24 percent of patients lying on standard mattresses. A 6-hour turning sc hedule for patients lying on a viscoelastic mattress resulted in simi lar outcomes, but a 4-hour turning schedule for patie nts lying on a visc oelastic mattress signific antly reduced stage II PUs. Other research suggests that turning ma y need to occur more frequently than every 2 hours and that sufficient pressure reduction surfaces are needed in addition to turning [32,34-36]. Recently, Vanderwee et al., using a pressure-reducing mattress, found no difference between repositioning patient s every 4 hours and alter nating between 2 hours in late ral and 4 hours in supine [36]. In both interventions, more than 16 percent of participants developed a PU. Additionally, two studies of secondary outcomes demonstrated that redness and oxygen reduction while lying in bed occurred in less than 2 hours [37]. Furthermore, in studies on turning, patients who are able will change posture between scheduled repositionings. As a result, these subjects are exposed to more position changes than offered by the intervention, which may mask a need for more frequent repositioning in those unable to reposition themselves [36]. The necessary repositioning frequency may be so high that implementation is impractical for immobile patients [32].

\section{Positioning Devices and Posture}

The entire premise behind turning is obviously to reduce the amount of time di fferent body surfaces are exposed to loading. Operati onally, many facilities sequence between supine and two side-lying postures. The loading at specific body surfaces is highly dependent on the resulting postures an $\mathrm{d}$ any positioning devices used. For example, side lying may expose a malleolus to damaging loading but proper positioning of the lower limbs and judicious use of positioning devices can effectively reduce loa ds from this bony prominence ( Figure 2(a)). Adopting a supine posture with the head of the bed elevated alters loading on the buttocks, which is why it is a controversial posture. Elevating only the head of the bed increases both the normal and frictional forces on the sacrum [38-39]. Mechanics suggests that as the head elevates, more of the upper-body weight will be transmitted through the buttocks to the supporting surface. In addition, the tendency to slide is increased as the trunk support is inclined. The complication is that it is a functional posture, adopted so people can converse with others, read, and eat, to name a fe w activities. Some of the fric tional forces can be counteracted by raising the foot of

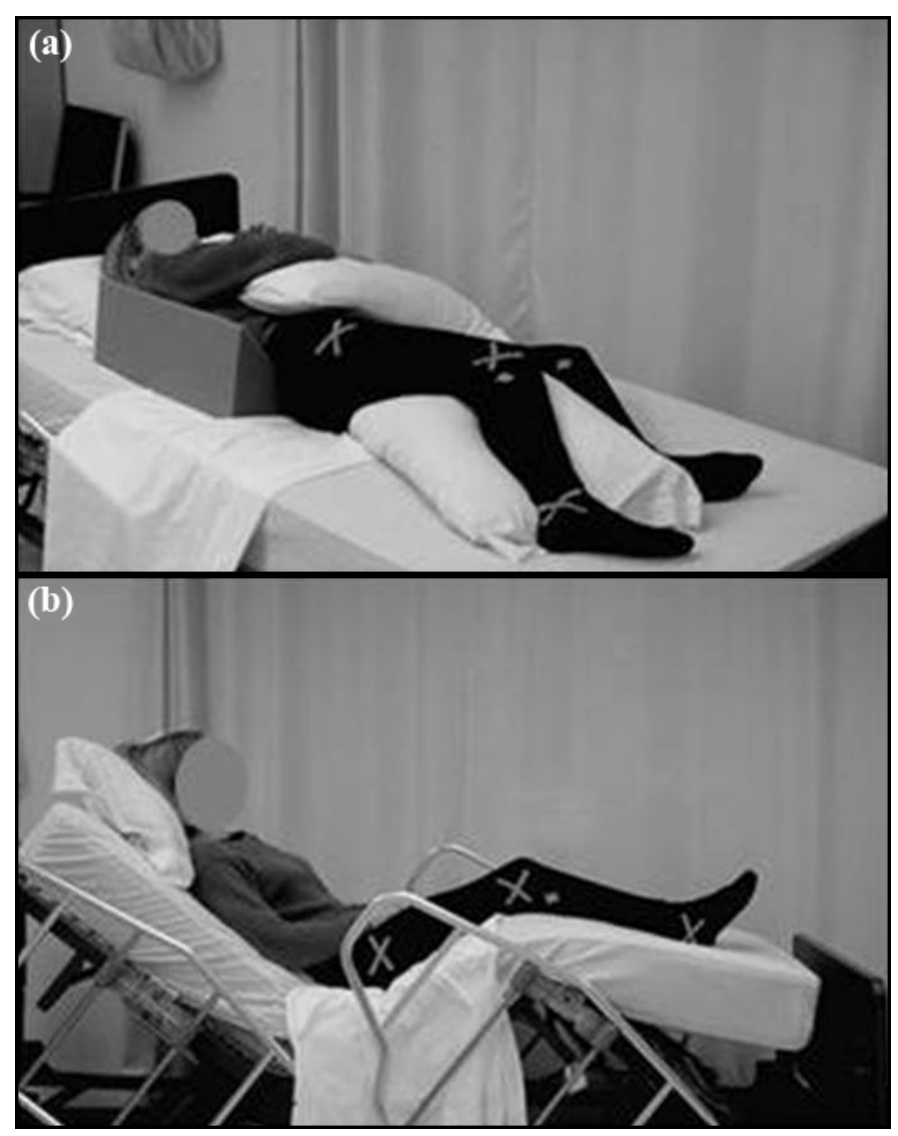

Figure 2.

(a) Use of positioning devices to redistribute pressure and (b) raising foot of bed counteracts sliding tendency. 
the bed, but this will not reduce the normal forces on the buttocks [38] (Figure 2(b)).

The seated posture also affects how loads are redistributed. Sitting on a sling seat with a pelvic obliquity induces asymmetric loading on the isch ial tuberosities, not to mention contributing to postural instability (Figure 3(a)). A slouched, kyphotic posture is typ ified by posterior pelvic tilt, a posture that loads the sacrum and coccyx while seated (Figure 3(b)) [40-41].

In summary, body posture and positioning have a direct relationship to loads on specific body sites, which is why posture must be co nsidered when devising PU prevention strategies.

\section{Weight Shifting}

Wheelchair users are often at high risk of developing sitting-acquired PUs. Persons with absent or diminished sensation and/or mobility are always at high risk of PUs [42-43]. A variety of maneuvers to shift body weight off the buttocks are taught to wheelchair users at risk of PUs. They can push down on the seat or armrests to lift the buttocks off the cushion surface (Figure 4(a)), lean forward to rest $t$ heir trunk upon the lower limbs (Figure 4(b)), or lean to one side and then lean to the opposite side (Figure 4(c)). Persons who use power wheelchairs and cannot independently perform these maneuvers are sometimes prescribed variable position wheelchairs that incorporate powered tilt and/or recline to redistribute weight off the buttock area (Figure 5).

Most guidelines that suggest weight shift or pressure relief frequency have been developed for $\mathrm{p}$ ersons with spinal cord injury (SCI) because of the effect of SCI on sensation and mobility. For the SCI po pulation, recommendations for weight shift frequency have typically ranged from 15 to 30 seconds every 15 to 30 minutes to 60 seconds every hour [44-47]. Based on the wide range of these guidelines, one can infer that they were based on a combination of clinical experience, clinical insight, and research findings.

In addition to weight shift frequency, one must also consider the duration for which a weight shift is held . In other words, not only do wheelchair users have to perform weight shifts regularly, they must attend to the duration of these maneuvers. The ability to sustain a weight shift is dependent on myriad factors, including functional ability, strength, flexibility, and postural control [46]. A 2003 study measured tissue perfusion to investigate the length of time required for tissue to reperfuse in an SCI cohort $(n=46)$
[48]. The mean duration of weight shift required to return transcutaneous partial pressure of oxygen to unloaded levels following upright sitting was $1 \mathrm{minu}$ te 51 seconds (range $=42-210$ seconds). This fin ding suggests that the

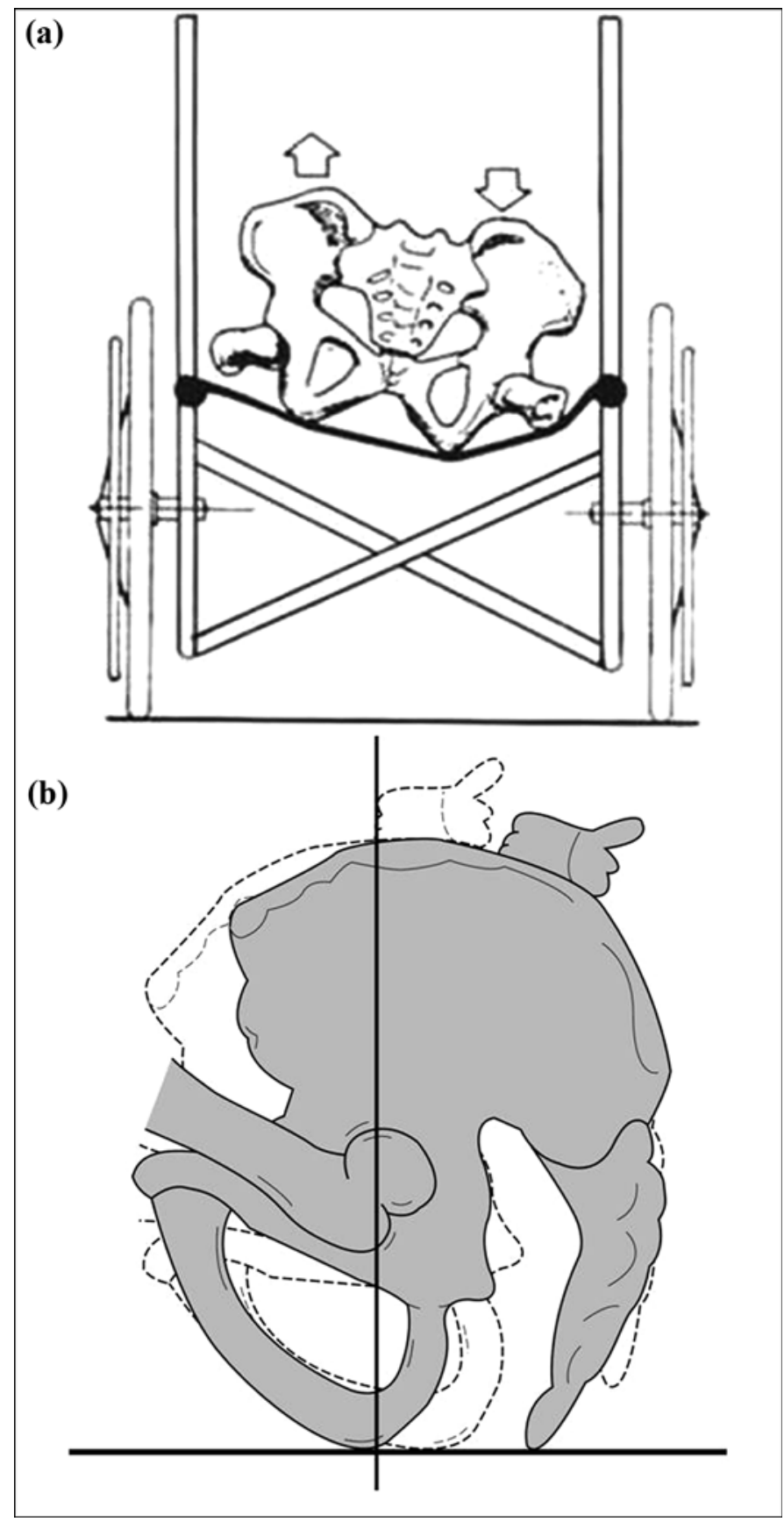

Figure 3.

(a) Pelvic obliquity from sitting on sling seat and (b) posterior pelvic tilt loads sacrum and coccyx. 


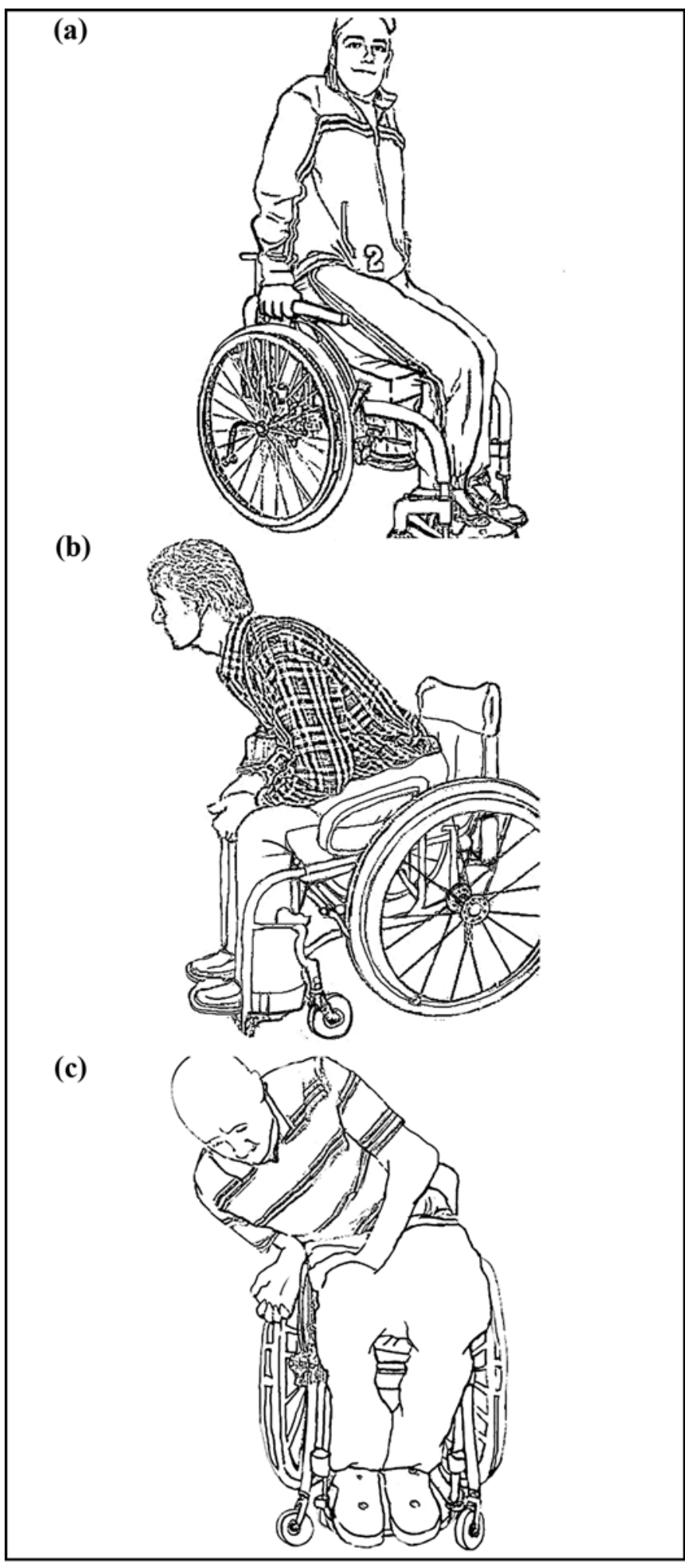

Figure 4.

(a) Push-up weight shift, (b) forward-lean weight shift, and (c) sidelean weight shift.

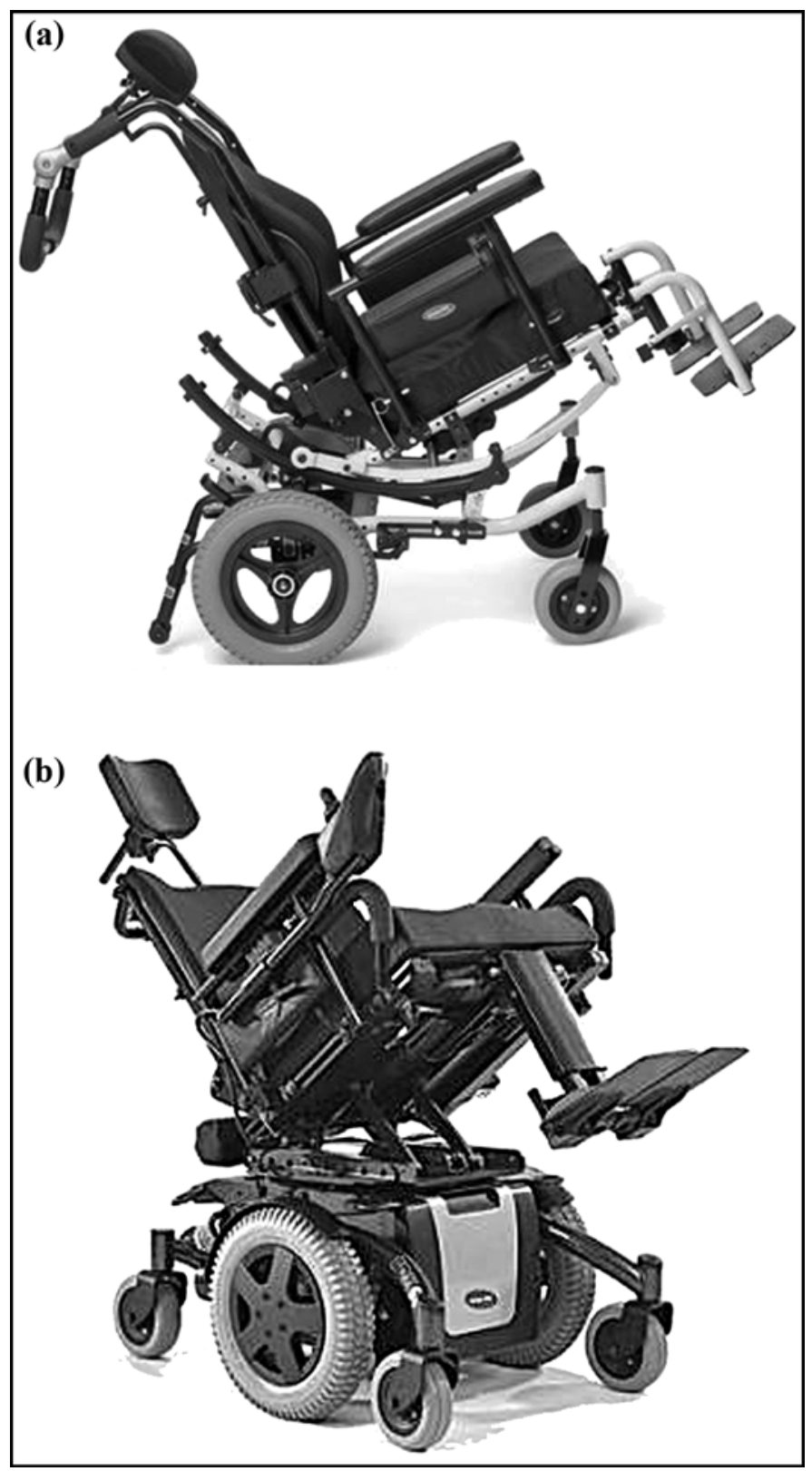

Figure 5.

(a) Manual Tilt-in-Space wheelchair and (b) Power T ilt-in-Space wheelchair. Images used with permission. ${ }^{\mathrm{C}}$ Invacare Corporation.

duration of weight shifts currently recommended (i.e., 1530 seconds) is inadequ ate. Further, this suggests that the common practice of sitting push-ups is not sustainable for many to achieve reperfusio $\mathrm{n}$. Consequently, the authors supported the use o f alternate, sustainab le methods of weight shift, namely fo rward lean, lateral lean, and rear ward tilt. Partial weight shifts may also allow for better sustainability by persons with SCI. 
Three recent studies inve stigating PU prevalence in an SCI cohort considered weight shift behavior as a potential risk factor [49-51]. None of the st udies found weight shift behavior or frequency of weight shifts to be associated with PU occ urrence. However, each of the studies used self-report to measure weight shift practices. Further objective analyses ar e needed to determine the role of weight shifts in PU prevention.

\section{CONCLUSIONS}

The review of res earch corroborated the clinical interventions commonly used for load redistribution but also identified areas of uncertainty. As with all means of prevention, some interventions are better supported than others and some interventions have a legacy quality to them and little el se. Nonetheless, several clinically oriented suggestions can be made.

\section{Support Surface Assessment}

Selections of mattre sses, overlays, and cushions should be based upon assessment. Research is clear that individual factors can contribute to PU susceptibility, and all the PU risk assessment scales are based upon indi vidualized evaluation. Research has also shown that individualized evaluation improves the selection of mattress [52] and wheelchair cus hions [53]. Long-standing evidence supports the use of seating clinics to select and prescribe wheelchair cushions [54]. One of the benefits of this type of individuali zed evaluation is its educational aspect in informing patients and clients about skin health and proper equipment use.

\section{Interface Pressure}

Interface pressure can be used to identify a reas of unacceptably high pressures and to ensure a site is adequately off-loaded during posture changes or a weight shift. We advocate for use of pressure mapping to rule out products rather than as a sole means to prescribe a particular product [21]. For exa mple, if the interface pressure under the ischial tuberosity is deemed too high for a particular person by a clinician, then the clinician should deem that p roduct unacceptable. That said, one cannot infer that published IPM values will generalize to other clients or patients. Another useful role for IPM is as sessing how posture or position changes influence loading on tissue. Repositioning in bed or while seated is necessary to unweight different parts of the body. IPM can offer visual feedback to clinicians, patients, and clients as they sequence through different postures.

\section{Weight Shift and Turning Frequency}

Periodic repositioning is an important preventative measure. Patients and clients who can independently redistribute pressure should be educated to do so and taught strategies to ensure compliance. Persons who cannot reposition must rely on others to set and follow a routine. Evidence on how often a weight shi ft should be performed and evidence behind turning schedules is limited. The odds are that repositioning frequency is not the same for all people and surfaces. This can be inferred by the wealth of evidence in dicating the individualized nature of PU risk and supports the approach that repositioning frequency should reflect the person, his or her equipment, and the environment of use.

- Standard hospital beds are poor support surfaces. Ample evidence has show $\mathrm{n}$ that standard mattresses are inadequate to prevent PU s. Even relati vely "low tech" mattresses and overlays offer better prevention [12].

- Increasing activity has many health benefits, including tissue health. In a study of more than 600 persons with SCI with and without a history of recurrent PUs, Krause and Broderick identified behaviors that were shown to be protective [50]. These behaviors included a healthy lifestyle, fitness, and exercise. Putting people into equipment and postures that permit functional activity addresses the key PU risk fac tor of immobility. We should promote reaching, leaning, and moving as a means of promoting functional independence and maintaining skin integrity.

- The European and U.S. National Pressure Ulcer Advisory panels have recently released their joint International Pressure Ulcer Guidelines for Prevention and Treatment. The document addresses both PU prevention and PU trea tment by assessing many clinical interventions.

- When reviewing conflicting literature, pay close attention to external validity. Literature regarding pressure redistribution and support surfaces is often equivocal and may be contradictory. This can oc cur because of differences in methods, measurements, and subjects. When reviewing literature, pay attention to how the studies reflect your clinical situation. P erhaps some studies better reflect your patient mix or techniques. 


\section{ACKNOWLEDGMENTS}

Author Contributions:

Study concept and design: S. Sprigle, S. Sonenblum.

Analysis and interpretation of data: S. Sprigle, S. Sonenblum.

Drafting of manuscript: S. Sprigle, S. Sonenblum.

Critical revision of manuscript for important intellectual content:

S. Sprigle, S. Sonenblum.

Administrative, technical, or material support: S. Sprigle,

S. Sonenblum.

Financial Disclosures: The authors have declared that no competing interests exist.

Funding/Support: This material was based on work supported by the Rehabilitation Engineering Research Center on Wheeled Mobility (Mobility RERC) and the Georgia Institute of Technology. The Mobility RERC is funded by the National Institute on Disability and Rehabilitation Research of the U.S. Department of Education (grant H133E080003).

Additional Contributions: We thank Dr. Kath Bogie for her guidance in outlining the manuscript and offering important feedback. Disclaimer: The opinions contained in this article are those of the authors and do not necessarily reflect those of the U.S. Department of Education or the Georgia Institute of Technology.

\section{REFERENCES}

1. Kosiak M. Etiology and pathology of ischemic ulcers. Arch Phys Med Rehabil. 1959;40(2):62-69. [PMID: 13618101]

2. Reswick JB, Rogers JE. Experience at Rancho Los Amigos Hospital with devices and techniques to prevent pressure sores. In: Kenedi RM, Cowden JM, Scales JT, editors. Bedsore biomechanics. Baltimore (MD): University Park Press; 1976. p. 301-10.

3. Dinsdale SM. Decubitus ulcers in swine: Light and electron microscopy study of pathogenesis. Arch Phys Med Rehabil. 1973;54(2):51-56. [PMID: 4692634]

4. Daniel RK, Wheatley D, Priest D. Pressure sores and paraplegia: An experimental model. Ann Plast Surg. 1985;15(1): 41-49. [PMID: 4083714] DOI:10.1097/00000637-198507000-00005

5. Linder-Ganz E, Gefen A. Mechanical compression-induced pressure sores in rat hindlimb: Muscle stif fness, histology, and computational models. J Appl Physiol. 2004;96(6): 2034-49. [PMID: 14766784] DOI:10.1152/japplphysiol.00888.2003

6. Lassen NA, Holstein P. Use of radioisotopes in assessment of distal blood flow and distal blood pressure in arterial insufficiency. Surg Clin North Am. 1974;54(1):39-55. [PMID: 4814522]

7. Holloway GA, Daly CH, Kennedy D, Chimoskey J. Effects of external pressure loadi ng on human skin blood flow measured by 133Xe clearance. J Appl Physiol. 1976;40(4): 597-600. [PMID: 931880]
8. Ek AC, Gustavsson G, Lewis DH. Skin blood flow in relation to external pressure an $d$ temperature in the supine position on a standard hospital mattress. Scand J Rehabil Med. 1987;19(3):121-26. [PMID: 3441774]

9. Sangeorzan BJ, Harrington RM, Wyss CR, Czerniecki JM, Matsen FA 3rd. Circulatory and mech anical response of skin to loading. J Orthop Res. 1989;7(3):425-31.

[PMID: 2703934] DOI:10.1002/jor.1100070315

10. Bennett L, Kavner D, Lee BK, Trainor FA. Shear vs pressure as causative factors in skin blood flow occlusion. Arch Phys Med Rehabil. 1979;60(7):309-14. [PMID: 454129]

11. Bar CA. The resp onse of tissues to applied pressure [dissertation]. [Cardiff (UK)]: University of Wales College of Medicine; 1988.

12. Cullum N, McIn nes E, Bell-Syer SE, Legood R. Support surfaces for pressure ulcer prevention. Cochrane Database Syst Rev. 2004;(3):CD001735. [PMID: 15266452]

13. Bar CA. Ev aluation of cushions using dynamic pressure measurement. Prosthet Orthot Int. 1991;15(3):232-40. [PMID: 1780227]

14. Ferguson-Pell MW, Wilkie IC, Reswick JB, Barbenel JC. Pressure sore prevention for the wheelchair-bound spinal injury patient. Paraplegia. 1980;18(1):42-51.

[PMID: 7375126]

15. Garber SL, Krouskop TA. Body build and its relationship to pressure distribution in the seated wheelchair patient. Arch Phys Med Rehabil. 1982;63(1):17-20. [PMID: 7055413]

16. Swain ID, Peters E. T he effects of posture, body mass index and wheelchair adjustment on interface pressure. Salisbury (England): Medical Devices Agency; 1997.

17. Brienza DM, Karg PE, Geyer MJ, Kelsey S, Trefler E. The relationship between pressure ulcer incidence and buttockseat cushion interface pressure in at-risk elderly wheelchair users. Arch Phys Med Rehabil. 2001;82(4):529-33.

[PMID: 11295017]

DOI:10.1053/apmr.2001.21854

18. Drummond D, Breed AL, Narechania R. Relationship of spine deformity and pelvic obliquity on sitting pressure distributions and decubitus ulceration. J Pediatr Orthop. 1985; 5(4):396-402. [PMID: 3894415]

19. Conine TA, Hershler C, Daechsel D, Peel C, Pearson A. Pressure ulcer prophylaxis in elderly patients using polyurethane foam or Jay wh eelchair cushions. Int J Reh abil Res. 1994;17(2):123-37. [PMID: 7960335] DOI:10.1097/00004356-199406000-00003

20. Oomens CW, Loerakker S, Bader DL. The importance of internal strain as opposed to interface pressure in the prevention of pressure related deep tissue injury. J Tissue Viability. 2010;19(2):35-42. [PMID: 20005716] DOI:10.1016/j.jtv.2009.11.002 
21. Pipkin L, Sprigle S. Effect of model design, cushion construction, and interface pressure mats on interface pressure and immersion. J Rehabil Res Dev. 2008;45(6):875-82.

[PMID: 19009473]

DOI:10.1682/JRRD.2007.06.0089

22. Reenalda J, Jannink M, Nederhand M, IJzerman M. Clinical use of interface pressure to predict pressure ulcer development: A systematic review. Assist Technol. 2009;21(2): 76-85. [PMID: 19715252] DOI:10.1080/10400430903050437

23. Stockton L, Rit halia S. Is dynamic seating a modality worth considering in the prevent ion of pressure ulcers? J Tissue Viability. 2008;17(1):15-21. [PMID: 18293767] DOI:10.1016/j.jtv.2007.09.011

24. Vanderwee K, Grypdonck M, Defloor T. Alternating pressure air mattresses as prevention for pressure ulcers: A literature review. Int J Nurs Stud. 2008;45(5):784-801.

[PMID: 17919638]

DOI:10.1016/j.ijnurstu.2007.07.003

25. De Looze MP, Kuijt-Evers LF, Van Dieën J. Sitting comfort and discomfort and the relationships with objective measures. Ergonomics. 2003;46(10):985-97. [PMID: 12850935] DOI:10.1080/0014013031000121977

26. Fenety PA, Putnam C, Walker JM. In-chair movement: Validity, reliability and implications for measuring sitting discomfort. Appl Ergon. 2000;31(4):383-93. [PMID: 10975665] DOI:10.1016/S0003-6870(00)00003-X

27. Grandjean E. Sitting pos ture of car drivers from the point of view of ergonomics. In: Oborne DJ, Levis JA, ed itors. Human factors in transport research. New York (NY): Academic Press; 1980. p. 240-48.

28. Reenalda J, Van Geffen P, Nederhand M, Jannink M, IJzerman M, Rietman H. An alysis of healthy sitting behavior: Interface pressure distribution and subcutaneous tiss ue oxygenation. J Rehabil Res Dev. 2009;46(5):577-86.

[PMID: 19882492] DOI:10.1682/JRRD.2008.12.0164

29. Richardson GM, Gardner S, Frant z RA. Nursing assessment: Impact on type and cost of interventions to prevent pressure ulcers. J W ound Ostomy Continence Nurs. 1998;25(6):273-80. [PMID: 9919142] DOI:10.1016/S1071-5754(98)90024-9

30. Hagisawa S, Ferguson-Pell M. Evidence supporting the use of two-hourly turning for pressure ulcer prevention. J Tissue Viability. 2008;17(3):76-81. [PMID: 18722313] DOI:10.1016/j.jtv.2007.10.001

31. Pressure ulcers in adults: Prediction and prevention. Washington (DC): Agency for Health Care Policy and Research; 1992.

32. Clark M. Repositioning to prevent pressure sores - What is the evidence? Nurs Stand. 1998;13(3):58-60. [PMID: 9847811]
33. Krapfl LA, Gray M. Does regular repositioning prevent pressure ulcers? J Wound Ostomy Continence Nurs. 2008; 35(6):571-77. [PMID: 19018196]

34. Defloor T, De Bacquer D, Grypdonck MH. The effect of various combinations of $t$ urning and pressure reducing devices on the incidence of pressure ulcers. Int J Nurs Stud. 2005;42(1):37-46. [PMID: 15582638]

DOI:10.1016/j.ijnurstu.2004.05.013

35. Gefen A. How much time do es it take to get a pressure ulcer? Integrated evidence from human, a nimal, and in vitro studies. Ostomy Wound Manage. 2008;54(10):26-28. [PMID: 18927481]

36. Vanderwee K, Grypdonck MH, De Bacquer D, Defloor T. Effectiveness of turning with unequal time intervals on the incidence of pressure ulcer lesions. J Ad v Nurs. 2007; 57(1):59-68. [PMID: 17184374] DOI:10.1111/j.1365-2648.2006.04060.x

37. Knox DM, Anderson TM, Anderson PS. Effects of different turn in tervals on skin of healthy older adults. Adv Wound Care. 1994;7(1):48-52. [PMID: 8149048]

38. Harada C, Shigematsu T, Hagisawa S. The effect of 10-degree leg elevation and 30-degree head elevation on body displacement and sacral interface pressures over a 2-hour period. J Wound Ostomy Continence Nurs. 2002;29(3):143-48. [PMID: 12011906] DOI:10.1067/mjw.2002.123645

39. Peterson M, Schwab W, McCutcheon K, Van Oostrom JH, Gravenstein N, Caruso L. Effects of elevating the head of bed on inte rface pressure in volunteers. Crit Care Med. 2008;36(11):3038-42. [PMID: 18824905] DOI:10.1097/CCM.0b013e31818b8dbd

40. Hobson DA, Tooms RE. Seated lumbar/pelvic alignment. A comparison between spinal cord-injured and noninjured groups. Spine. 1992;17(3):293-98. [PMID: 1566167] DOI:10.1097/00007632-199203000-00009

41. Sprigle S, S chuch JZ. Using seat contour measurements during seating evaluations of in dividuals with SCI. Assist Technol. 1993;5(1):24-35. [PMID: 10148621] DOI:10.1080/10400435.1993.10132204

42. Bergstrom N, Braden B, Boynton P, Bruch S. Using a research-based assessment scale in clinical practice. Nurs Clin North Am. 1995;30(3):539-51. [PMID: 7567578]

43. Salzberg CA, Byrne DW, Cayten CG, Van Niewerburgh P, Murphy JG, Viehbeck M. A new pressure ulcer risk assessment scale for in dividuals with spinal cord injury. Am J Phys Med Rehabil. 1996;75(2):96-104. [PMID: 8630201] DOI:10.1097/00002060-199603000-00004

44. Regan M, Teasell RW, Keast D, Mortenson WB, Aubut J. Pressure ulcers following spinal cord in jury. In: Eng JJ, Teasell RW, Miller WC, Wolfe DL, Townson AF, Aubut JA, Abramson C, Hsieh JT, Connolly S, edit ors. Spinal 
cord injury rehabilitation evidence. Vancouver (Canada): SCIRE; 2006.

45. Alverzo JP, Rosenberg JH, Sorensen CA, DeLeon SS. Nursing care and education for patients with spinal cord injury. In: Sisto SA, Druin E, Sliwinski MM, editors. Spinal cord injuries: Management and rehabilitation. St. Louis (MO): Mosby; 2009. DOI:10.1016/B978-032300699-6.10003-6

46. Sliwinski MM, Druin E. Intervention principles and position change. In: Sisto SA, Druin E, Sliwinski MM, editors. Spinal cord injuries: Management and rehabilitation. St. Louis (MO): Mosby; 2009. DOI:10.1016/B978-032300699-6.10007-3

47. Nawoczenski DA. Pressure sores: Prevention and management. In: Buchanan LE, Nawo czenski DA, editors. Spinal cord injury: Concepts and management approaches. Baltimore (MD): Williams \& Wilkins; 1987.

48. Coggrave MJ, Rose LS. A s pecialist seating asses sment clinic: Changing pressure relief practice. Spinal Cord. 2003;41(12):692-95. [PMID: 14639449]

DOI:10.1038/sj.sc.3101527

49. Raghavan P, Raza WA, Ahmed YS, Chambe rlain MA. Prevalence of pressure sores in a community sample of spinal injury patients. Clin Rehabil. 2003;17(8):879-84.

[PMID: 14682560] DOI:10.1191/0269215503cr692oa

50. Krause JS, Broderick L. Patterns of recu rrent pressure ulcers after s pinal cord injury: Identification of risk and protective factors 5 or more years after onset. Arch Phys Med Rehabil. 2004;85(8):1257-64. [PMID: 15295750] DOI:10.1016/j.apmr.2003.08.108
51. Garber SL, Rintala DH, Ha rt KA, Fuhrer MJ. Pressure ulcer risk in spinal cord injury: Predictors of ulcer status over 3 years. Arch Phys Med Rehabil. 2000;81(4):465-71. [PMID: 10768537]

DOI:10.1053/mr.2000.3889

52. Russell T, Bsn AL, Lohman JA. A medical center's experience with managing specialty bed usage. J Wound Ostomy Continence Nurs. 2001;28(6):274-78. [PMID: 11707759] DOI:10.1067/mjw.2001.119011

53. Garber SL, Dyerly LR. Wheelchair cushions for persons with spinal cord injury: An update. Am J Occup Ther. 1991;45(6):550-54. [PMID: 2063944]

54. Krouskop TA, Noble PC, Garber SL, Spencer WA. The effectiveness of preventive management in reducing the occurrence of pressu re sores. J Rehabil Res Dev. 1983; 20(1):74-83. [PMID: 6887068]

Submitted for publication May 26, 2010. Accepted in revised form August 16, 2010.

This article and any supplementary material should be cited as follows:

Sprigle S, Sonenblum S. As sessing evidence supporting redistribution of pressure for pressure ulcer prevention: A review. J Rehabil Res Dev. 2011;48(3):203-14.

DOI:10.1682/JRRD.2010.05.0102

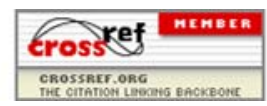


